\title{
OS CRIMES CONTRA AS RELAÇÕES DE CONSUMO NO CÓDIGO DE DEFESA DO CONSUMIDOR
}

\section{CRIMININI CONTRO LA RELAZIONE DI CONSUMO NEL CODICE DI DIFESA DEL CONSUMATORE}

${ }^{1}$ Gleice Leila Barral

\section{RESUMO}

Este artigo visa analisar os crimes contra as relações de consumo previstos no Código de Defesa do Consumidor. Partindo de um breve relato acerca do contexto histórico em que surgiu o Código de Defesa do Consumidor e dos eventos que determinaram a criação de um microssistema repleto de normas sancionatórias de caráter penal, identificaremos os elementos dos crimes contra as relações de consumo, tais como: o sujeito ativo, o sujeito passivo, o objeto material e jurídico da tutela penal. Tendo em vista a questão levantada, a pesquisa que se propõe mostra-se de grande relevância, na medida que tem como intuito fornecer aos consumidores informações capazes de auxilia-los na defesa de seus direitos e também, na busca de maior efetividade dos tipos penais analisados.

Palavras-chave: Crimes, Relação de consumo, Código de defesa do consumidor

\section{RÉSUMÉ}

Questo articolo si propone analizzare i crimini contro le relazioni di consumo. Partendo da una breve considerazione sul contesto storico in cui è apparso il codice di difesa del consumatore e gli eventi che hanno portato alla creazione di un microsistema pieno di norme con carateristiche penali, identificheremo gli elementi dei crimini contro i rapporti di consumo, quali: soggetto attivo, il soggetto pasivo, l'oggetto materiale e 1 oggetto giuridico di tutela penale. Considerando la questione alzata, questa ricerca diventa rilevante nella misura che cerca fornire al consumatore informazioni che li possono aiutare a difendere i loro diritti e anche nella ricerca di una maggiore efficacia dei tipi di penali analizzati.

Mots-clés: Crimini, Rapporto di consumo, Codice di difesa del consumatore

\footnotetext{
${ }^{1}$ Mestre em Instituições Sociais, Direito e Democracia pela Fundação Mineira de Educação e Cultura - FUMEC, Minas Gerais (Brasil). E-mail: glbarral@yahoo.com.br
} 


\section{INTRODUÇÃO}

Durante o paradigma do Estado Liberal os contratos tinham como fundamento a autonomia da vontade, ou seja, os contratantes tinham plena liberdade para pactuar as regras contratuais de acordo com suas vontades, sem intervenção do Estado nas relações entre os particulares.

Com o crescimento da industrialização, e principalmente, a partir do fenômeno mundial das relações de consumo, massificado pelo crescente aumento da oferta de produtos e serviços, crescimento do marketing e propagação do crédito, o modelo paradigmático até então existente tornou-se insustentável, sendo imprescindível a intervenção do Estado nas relações entre os particulares.

Tendo em vista estas mudanças ocorridas, e ainda, o surgimento de um provável desequilíbrio entre os contratantes, o Estado passou a intervir nas relações, impondo determinadas condutas às partes, reduzindo a infinda autonomia de maneira a assegurar o justo equilíbrio e harmonização das relações.

Segundo Cristiano Chaves de Farias a sociedade desde o século XX tem se organizado a partir do fenômeno mundial das relações de consumo e é nesse "panorama da 'revolução das massas' que surge a necessidade de equilibrar as relações sociais, marcadas por um desnível natural imposto pelas diferentes posições e interesses das partes envolvidas". (FARIAS, 2002, p. 84).

Na relação de consumo, não dispondo os consumidores de controle sobre a produção dos objetos de consumo que lhe são destinados, acabam submetendo-se as condições e exigências impostas pelo economicamente mais forte, provocando o desequilíbrio na relação. Em razão desse desequilíbrio, tornou-se necessário a criação de mecanismos legais capazes de proteger e colocar os consumidores em posição de igualdade com os fornecedores, a fim de estabelecer o equilíbrio de forças e a efetivação do principio da isonomia.

Assim, como forma de trazer o equilíbrio na relação de consumo o Código de Defesa do Consumidor prescreveu normas contratuais rígidas, submeteu o fornecedor as regras de responsabilidade civil objetiva, trouxe diversas normas relacionadas à efetivação dos direito e facilitação de defesa, propriamente, na esfera cível e, acertadamente, prescreveu um sistema sancionatório de caráter administrativo e penal.

A instituição dos crimes de consumo assumem papel muito importante na defesa dos direitos dos consumidores, contudo, a de se reconhecer que os consumidores nem sempre são 
estimulados a denunciar as infrações contra eles cometidas, seja, por comodismo, ausência de credibilidade na justiça ou mesmo falta de informações acerca dos tipos penais.

Neste sentido, o presente artigo tem como objetivo analisar os crimes contra as relações de consumo previstos no Código de Defesa do Consumidor. Partindo de um breve relato acerca do contexto histórico em que surgiu o Código de Defesa do Consumidor e dos eventos que determinaram a criação de um microssistema repleto de normas sancionatórias de caráter penal, identificaremos os elementos dos crimes contra as relações de consumo, tais como: o sujeito ativo, o sujeito passivo, o objeto material e jurídico da tutela penal.

Tendo em vista a questão levantada, a pesquisa que se propõe mostra-se de grande relevância, na medida em que tem como intuito fornecer aos consumidores informações capazes de auxilia-los na defesa de seus direitos e também, na busca de maior efetividade dos tipos penais analisados.

\section{O SISTEMA DE PROTEÇÃO DO CONSUMIDOR NO DIREITO BRASILEIRO}

A inspiração para elaboração do Código de Defesa do Consumidor decorreu diretamente da Constituição Federal, que ao cuidar dos direitos e garantias fundamentais, dispôs no art. $5^{\circ}$, XXXII e art. $170, \mathrm{~V}$, que caberia ao Estado promover e assegurar a defesa dos direitos dos consumidores, como um dos fundamentos da ordem econômica.

O Código de Defesa do Consumidor foi instituído em razão da norma contida no art. 48 do Ato das Disposições Constitucionais Transitórias, que identificou o consumidor como agente de proteção e determinou ao legislador que dentro de 120 (cento e vinte) dias da promulgação da Constituição, elaborasse o mencionado Código.

Segundo Ada Pellegrini Grinover e Antônio Herman de Vasconcelos e Benjamin (2001), integrantes da Comissão constituída para a elaboração da legislação consumerista. O Código buscou inspiração nos modelos legislativos já existentes, entretanto, tomou-se o cuidado de evitar transcrição de "textos alienígenas", uma vez que o mercado de consumo brasileiro tem características e problemas próprios.

Desta forma, embora seja possível identificar no referido Código a influência de outros ordenamentos, vários são os dispositivos que foram adaptados exclusivamente ao mercado de consumo brasileiro.

Grinover e Benjamin descrevem, ainda, as principais inovações trazidas pelo Código: 
Quanto às inovações trazidas cabe ressalvar as seguintes: a formulação de um conceito amplo de fornecedor, incluindo, a um só tempo, todos os agentes econômicos que atuam, direta ou indiretamente, no mercado de consumo, abrangendo inclusive as operações de crédito e securitárias ; um elenco de direitos básicos dos consumidores e instrumentos de implementação; proteção contra todos os desvios quantidade e qualidade (vícios de qualidade por insegurança e vícios de qualidade por inadequação); melhoria do regime jurídico dos prazos prescricionais e decadenciais; ampliação das hipóteses de desconsideração da personalidade jurídica das sociedades; regramento do marketing (oferta e publicidade); controle das práticas e cláusulas abusivas, bancos de dados e cobrança de dívidas de consumo; introdução de um sistema sancionatório administrativo e penal; facilitação do acesso à justiça para o consumidor; incentivo à composição privada entre consumidores e fornecedores, notadamente com a previsão de convenções coletivas de consumo. (GRINOVER; BENJAMIN, 2001, p. 11).

Respeitando os valores entalhados na Constituição Federal, o microssistema de defesa do consumidor nasceu com princípios próprios e regras fundamentais de ordem pública. O que significa dizer que suas normas têm incidência obrigatória, não podendo, pois, ser afastadas por simples vontade dos envolvidos na relação de consumo.

Deste modo, não cabe ao consumidor renunciar a quaisquer direitos que o Código lhe outorgue, assim como, não pode o fornecedor furtar-se de quaisquer responsabilidades que o Código lhe imponha.

Como forma a trazer o equilíbrio na relação de consumo o Código de Defesa do Consumidor prescreveu normas contratuais rígidas, submeteu o fornecedor as regras da responsabilidade civil objetiva, fixou regras e prazos quanto aos vícios, e ainda, conferiu ao consumidor, como instrumentos de defesa a possibilidade de inversão do ônus da prova no processo judicial. (FARIAS, 2002).

Não obstante, o Código de Defesa do Consumidor tenha trazido diversas normas relacionadas à efetivação dos direito e facilitação de defesa, propriamente, na esfera cível, o microssistema, acertadamente, também prescreveu nos artigos 55 a 80, um sistema sancionatório de caráter administrativo e penal.

As sanções de caráter administrativo encontram-se previstas nos art. 55 a 60 e estão relacionadas à observância de normas relativas à produção, industrialização, distribuição e consumo de produtos e serviços. Impondo ao produtor e ao fornecedor, nos casos de violação, sanções administrativas, tais como: multa, apreensão e inutilização do produto, cassação do alvará de licença, proibição de fabricação e fornecimento do produto, etc.

Destaque-se que a imposição das sanções administrativas tem caráter objetivo, ou seja, independe da existência de dolo ou culpa, cabendo ainda, a sua imposição cumulativamente e sem prejuízo das penalidades de natureza cível e penal, desde que não sejam incompatíveis entre si. 
Quanto às infrações de natureza penal essas se encontram elencadas no Titulo II, que abrange os artigos 61 e seguintes do CDC, que assim dispõe: "Constituem crimes contra as relações de consumo previstas neste código, sem prejuízo do disposto no Código Penal e leis especiais ${ }^{1}$, as condutas tipificadas nos artigos seguintes" (BRASIL, 1990).

O mencionado dispositivo afirma que os crimes elencados são praticados em detrimento das "relações de consumo" e não diretamente contra o consumidor. Isso porque os crimes previstos no Código de Defesa do Consumidor tutelam de modo imediato as relações de consumo e de forma indireta a vida, a saúde e integridade física do consumidor.

Segundo Cláudia Lima Marques:

\begin{abstract}
O bem jurídico tutelado é a relação de consumo, não na sua dimensão individual (um consumidor versus um fornecedor), mas na sua pespectiva supra- individual, perspectiva esta que nem sempre decorre do dado factual, mas sim de uma imposição do legislador. Tanto assim, que o CDC, ao mencionar o bem jurídico tutelado, refere-se a "crimes contra as relações de consumo", colocando estas no plural. (MARQUES, et al. 2006, p.889).
\end{abstract}

Cabe ressaltar que antes da inclusão dessas normas penais no Código de Defesa do Consumidor a proteção das relações de consumo era feita de forma indireta e incompleta, por outras legislações.

Os primeiros crimes de consumo surgiram com o advento do Decreto-Lei $\mathrm{n}^{\circ}$. 869, de 18 de novembro de 1938, que definia os delitos contra a economia popular sua guarda e seu emprego. A esse diploma sobreveio a Lei $\mathrm{n}^{\circ} .1 .521$ de 26 de dezembro de 1951, que nada mais fez do que alterar os dispositivos então vigentes.

Seguida à promulgação do Código de Defesa do Consumidor, sobreveio a Lei $\mathrm{n}^{\circ}$. $8.137 / 90$, que surgiu no cenário jurídico, com o objetivo de reprimir os crimes contra a ordem tributária, econômica e contra as relações de consumo. As novas infrações penais reunidas no $\operatorname{art} .7^{\circ}$ se assemelham as previstas no microssistema consumerista.

Para Marco Antônio Zanellato:

\begin{abstract}
A citada Lei $\mathrm{n}^{\circ}$. 8.137/90, ao definir crimes contra a ordem tributária, econômica e contra as relações de consumo, preencheu, junto com o Código de Defesa do Consumidor, a nosso ver, a grande lacuna que existia no campo da repressão da criminalidade econômica, repressão esta perseguida desde a edição da Lei $\mathrm{n}^{\circ}$. 1.521, de 26 de dezembro de 1951, ou seja, há cerca de quarenta anos. (ZANELLATO, 1992, p. 87).
\end{abstract}

\footnotetext{
${ }^{1}$ Caso haja conflitos entre os delitos, o mesmo será dirimido pelo principio da especialidade, segundo o qual a existência de lei especial afasta a incidência de uma lei geral - lex especialis derogat legi generali.
} 
Eduardo Gabriel Saad relaciona, ainda, várias legislações extravagantes de índole penal que tem por objeto os crimes contra o consumidor e cita, além das já mencionadas, a Lei nº 8.884 de 11 de junho de 1994 (Lei Antitruste). (SAAD, 1999)

Registre-se que o consumidor também se encontra protegido pelo Código Penal Brasileiro, que prevê nos artigos 267 a 285, punições para crimes praticados em detrimento da saúde pública.

\section{DOS CRIMES CONTRA AS RELAÇÕES DE CONSUMO}

Inicialmente, é importante ressaltar que as infrações tipificadas nos artigos 63 a 74, são na sua maioria, crimes de perigo, assim entendidos, como aqueles crimes em que a sua consumação se dá tão somente com a possibilidade do dano, não sendo necessário que haja uma lesão efetiva ao bem jurídico tutelado.

Cezar Roberto Bitencourt define crime de perigo como sendo aquele:

[...] que se consuma com a simples criação do perigo para o bem jurídico protegido, sem produzir um dano efetivo. Nesses crimes o elemento subjetivo é o dolo de perigo cuja vontade limita-se à criação da situação de perigo, não querendo o dano, nem mesmo, eventualmente. $\mathrm{O}$ perigo, nesses crimes, pode ser concreto ou abstrato: Concreto é aquele que precisa ser comprovado, isto é, deve ser demonstrada a situação de risco corrida pelo bem jurídico protegido. O perigo só é reconhecível por uma valoração subjetiva da probabilidade de superveniência de um dano. $\mathrm{O}$ perigo abstrato é presumido juris et de jure. Não precisa ser provado, pois a lei contenta-se com a simples pratica da ação que pressupõe perigosa. (BITENCOURT, 20003, p.148).

Assim, enquanto nos crimes de dano exige-se para a consumação uma lesão efetiva, podendo, a ausência representar mera tentativa ou um indiferente penal, nos crimes de perigo a simples exposição do bem jurídico é suficiente para tornar consumada a infração. (BITENCOURT, 2003)

Todavia se, com o exaurimento, ocorrer dano relevante para o direito penal, como na hipótese de desdobramento da conduta em lesão corporal ou homicídio, haverá aplicação cumulativa das penas previstas no Código de Defesa do Consumidor e do Código Penal Brasileiro. Antônio Herman V. Benjamim ao discorrer sobre o tema leciona:

\footnotetext{
Os tipos penais de proteção ao consumidor, como regra e em razão da presunção de perigo que acarretam, não exigem, para a sua consumação, a realização de qualquer dano físico, mental ou econômico ao individuo-consumidor. Todavia, no caso brasileiro, uma vez presente qualquer destas consequências gravosas, impõe-se, como derivação da autonomia do bem jurídico de consumo (CDC, art. 61), o
} 
concurso com tipos comuns (por exemplo, os arts. 121,129 e 171 todos do CP). (BENJAMIN, 2006, p. 896).

A doutrina descreve, ainda, os crimes previstos no Código de Defesa do Consumidor como sendo, em sua maioria, crimes de mera conduta, assim entendidos como aqueles "no qual o legislador descreve somente o comportamento do agente, sem preocupar com o resultado”. (BITENCOURT, 2003, p.168).

Segundo Nascimento essa qualificação dos crimes prevista no Código de Defesa do Consumidor é importante para se concluir que, em muitos crimes, não há possibilidade de se configurar a forma tentada. (NASCIMENTO, 1991)

O art. 14, II do Código Penal dispõe que só há tentativa quando o resultado natural não é alcançado por "circunstâncias alheias à vontade do agente". Como os crimes de mera conduta, em sua maioria, não se preocupam com o resultado, não é possível pensar em tentativa. Isso porque, ou há crime consumado pela simples conduta, ou não existe o crime.

\section{SUJEITOS E OBJETO DOS CRIMES CONTRA AS RELAÇÕES DE CONSUMO}

Segundo definição de Nelson Nery Junior "relação de consumo é a relação jurídica formada entre fornecedor e consumidor, tendo por objeto produto ou serviço" (NERY JÚNIOR, 1998, p.15).

A partir dessa definição podemos dizer que as infrações tipificadas no Código de Defesa do Consumidor têm como sujeito ativo do crime, o fornecedor; como sujeito passivo os consumidores, e como, objeto material, o produto ou serviços disponibilizado no mercado de consumo.

\subsection{Sujeito Passivo: o consumidor}

O sujeito passivo do crime é o titular do bem jurídico lesado ou ameaçado pela conduta delitiva. Segundo Fernando Galvão o sujeito passivo pode ser um individuo, ainda que civilmente incapaz, mas nunca uma “coisa”, podendo ainda, ser sujeito passivo a pessoa jurídica e o Estado. Contudo, observa o autor que alguns crimes nem sempre possuem um sujeito passivo determinado, isso porque a conduta perpetrada pode ofender, simultaneamente, vários sujeitos passivos, materializando a possibilidade de ofensa a um número indeterminado de pessoas. (GALVÃO, 2007). 
Sendo os crimes praticados em detrimento "das relações de consumo", poderíamos dizer que o sujeito passivo, neste caso, seria o consumidor, seja na sua perspectiva coletiva ou individual.

O Código de Defesa do Consumidor apresenta quatro conceitos para a expressão “consumidor", ou seja: I) o conceito padrão ${ }^{2}$; II) a coletividade de pessoas, ainda que indetermináveis, que haja intervindo nas relações de consumo; III) as vítimas de acidente de consumo e; IV) aquele que estiver exposto às praticas comerciais, tais como publicidade, oferta, práticas comerciais abusivas, etc.

O conceito padrão de consumidor encontra-se previsto no caput do art. $2^{\circ}$ do Código de Defesa do Consumidor, o qual estabelece que "consumidor é toda pessoa física ou jurídica que adquire ou utiliza produto ou serviço como destinatário final”. (BRASIL, 1990).

Neste sentido, leciona Arruda Alvim que :

\begin{abstract}
$\mathrm{O}$ conceito geral de consumidor, estabelecido neste art. $2^{\circ}$, refere-se explicitamente à aquisição ou utilização em caráter final, não contemplando como consumidores, genericamente, aqueles que adquirem e revendem o mesmo produto, ou apenas adquirem o produto para transformá-lo ou mesmo implementá-lo em outro. (ARRUDA ALVIM, et al., 1995, p.30)
\end{abstract}

Quanto ao conceito de consumidor por equiparação legal, o parágrafo único do art. $2^{\circ}$ traz um conceito de consumidor, não encarado de maneira isolada, mas de forma coletiva, segundo o referido artigo: "equipara-se a consumidor a coletividade de pessoas, ainda que indetermináveis, que indetermináveis, que haja intervindo nas relações de consumo”. (BRASIL, 1990).

Por equiparação legal, o art. 17 o Código de Defesa do Consumidor do dispõe que "para os efeitos desta seção, equiparam-se aos consumidores todas as vítimas do evento". (BRASIL, 1990).

Já o art. 29 do mesmo diploma legal, ao fazer referência aos Capítulos V e VI, que tratam, respectivamente, "das práticas comerciais" e "da proteção contratual", considerou-se consumidor toda pessoa determinável ou não, exposta às práticas previstas nos capítulos referidos anteriormente.

Assim, todos aqueles que se encontrarem exposto às ofertas, práticas comerciais abusivas, publicidade, etc., são igualmente consumidor, independentemente de haver ou não adquirido o produto ou se utilizado do serviço.

\footnotetext{
${ }^{2}$ Também conhecida como consumidor stricto sensu ou standart.
} 


\subsection{Sujeito Ativo}

Para Fernando Galvão: "o sujeito ativo do delito do delito é a pessoa humana que comete o ilícito penal”. (GALVÃO, 2007, p. 165). A partir desta definição, podemos dizer que o sujeito ativo, nos crimes contra as relações de consumo seria qualquer fornecedor de produtos ou serviços. Assim entendido, conforme art. $3^{\circ}$ do Código Defesa do Consumidor, como:

Toda pessoa física ou jurídica, pública ou privada, nacional ou estrangeira, bem como os entes despersonalizados, que desenvolvem atividade de produção, montagem, criação, construção, transformação, importação, exportação, distribuição ou comercialização de produtos ou prestação de serviços. (BRASIL, 1990).

Contudo, é mister fazer uma ressalva, já que a nossa legislação não admite a responsabilização penal da pessoa jurídica, salvo casos excepcionais. ${ }^{3}$

Para Nelson Nery Júnior, no sentido do Código, fornecedor "é todo aquele, que pratica alguma atividade no mercado, notadamente o produtor, o comerciante e o prestador de serviços." (NERY, 2001, p.53).

Neste mesmo sentido, Filomeno diz que:

Fornecedor "é qualquer pessoa física, ou seja, qualquer um que, a titulo singular, mediante desempenho de atividade mercantil ou civil e de forma habitual, ofereça no mercado produtos ou serviços, e a jurídica, da mesma forma, mas em associação mercantil ou civil e de forma habitual" (FILOMENO, 2001, p.39).

O conceito abrange, também, os fornecedores nacionais, os estrangeiros que exportem produtos ou serviços no País e ainda, considera fornecedor os entes despersonalizados, assim entendidos, os que, "não dotados de personalidade jurídica, quer no âmbito mercantil, quer no civil, exerçam atividades produtivas de bens e serviços.” (FILOMENO, 2001, p. 40).

James Marins observa que: "somente aqueles que participam do fornecimento de produtos e serviços no mercado de consumo com caráter de profissionalidade (exercício habitual do comércio) é que estão sujeitos as norma deste Código.” (MARINS, 1993, p. 120).

Essa observação é altamente esclarecedora, sobretudo, em razão de norma contida no art. 75 do CDC, que identifica, também, como sujeito ativo dos crimes contra as relações de

\footnotetext{
3 A Constituição Federal somente admite a responsabilização penal da pessoa jurídica em razão de atos praticados contra a ordem econômica e financeira e contra a economia popular (art. $\left.173, \S 5^{\circ}\right)$ e nos crimes ambientais (art. 225, $\S 3^{\circ}$ ).
} 
consumo: o diretor, o administrador ou gerente da empresa fornecedora ou prestadora de serviços.

\begin{abstract}
Art. 75. Quem, de qualquer forma, concorrer para os crimes referidos neste código, incide as penas a esses cominadas na medida de sua culpabilidade, bem como o diretor, administrador ou gerente da pessoa jurídica que promover, permitir ou por qualquer modo aprovar o fornecimento, oferta, exposição à venda ou manutenção em depósito de produtos ou a oferta e prestação de serviços nas condições por ele proibidas. (BRASIL, 1990).
\end{abstract}

Segundo Eduardo Gabriel Saad, para a lei penal pouco importa saber quem é o dono da empresa, mais importante é saber quem realmente praticou o ato criminoso, nas palavras do autor:

\begin{abstract}
Não é suficiente, para o fiel cumprimento das disposições penais do Código, que se identifiquem o administrador ou diretores da empresa responsável pelo produto defeituoso ou pelo serviço imperfeito que lesaram o patrimônio do consumidor. È mister que se saiba quem praticou o ato incriminador. (SAAD, 1999, p. 520).
\end{abstract}

Em decisão proferida nos autos do $\mathrm{HC} 88.077 / \mathrm{RS}^{4}$, os ministros do Supremo Tribunal Federal denegaram a ordem, já pleiteada no Superior Tribunal de Justiça (RHC 17.161) ${ }^{5}$, por um superintendente industrial e uma engenheira química. Ambos os pacientes eram funcionários de uma empresa fabricante de refrigerantes e respondiam pela prática dos delitos previstos no art. $7^{\circ}$, IX e Parágrafo Único c/c art.11, caput da Lei ${ }^{\circ}$. 8.137/90 ${ }^{6}$, e também, art. 64 do Código de Defesa do Consumidor.

\footnotetext{
${ }^{4}$ EMENTA: AÇÃO PENAL. Crime contra a saúde pública. Colocação, no mercado, de duas garrafas de refrigerante impróprio para consumo. Art. $7^{\circ}$, inc. IX e $\S$ único, cc. art. 11, caput, da Lei $n^{\circ} 8.137 / 90$. Fato típico. Princípio da insignificância. Impossibilidade de reconhecimento em habeas corpus. Delito que atenta de imediato contra as relações de consumo. HC denegado. Constitui, em tese, delito contra as relações de consumo, por no mercado refrigerantes em condições impróprias para consumo. (HC 88077, Relator Min. CEZAR PELUSO. $2^{\mathrm{a}}$ Turma, Julgado: 31/10/2006. DJ 16/02/2007).

${ }^{5}$ EMENTA. RECURSO ORDINÁRIO EM HABEAS CORPUS. ARTIGO $7^{\circ}$, INCISO IX, E PARÁGRAFO ÚNICO, C/C 11, CAPUT, DA LEI N. ${ }^{\circ}$ 8137/90. TRANCAMENTO DA AÇÃO PENAL: ATIPICIDADE. EXAME APROFUNDADO DE PROVAS. INADEQUAÇÃO DA VIA ELEITA. PRINCÍPIO DA INSIGNIFICÂNCIA. CRIME CONTRA A RELAÇÃO DE CONSUMO. BEM JURÍDICO TUTELADO: SAÚDE. INAPLICABILIDADE. 1. O trancamento da ação penal pela via de habeas corpus é medida de exceção, que só é admissível quando emerge dos autos, de forma inequívoca, a inocência do acusado, a atipicidade da conduta ou a extinção da punibilidade, hipóteses não verificadas no caso. 2.0 princípio da insignificância, como derivação necessária do princípio da intervenção mínima do Direito Penal, busca afastar de sua seara as condutas que, embora típicas, não produzam efetiva lesão ao bem jurídico protegido pela norma penal incriminadora. 3. Trata-se, na hipótese, de crime em que o bem jurídico tutelado é a saúde pública, tornando irrelevante considerar a quantidade de garrafas impróprias para o consumo para alvitrada desqualificação penal da conduta. 4. Recurso improvido. (RHC 17.161/2005/0002075-0. Relator: Ministro Hélio Quaglia Barbosa. DJ 13/02/2006.

${ }^{6}$ Art. 11. Quem, de qualquer modo, inclusive por meio de pessoa jurídica, concorre para os crimes definidos nesta lei, incide nas penas a estes cominadas, na medida de sua culpabilidade. (BRASIL, 1990).
} 
Igualmente, os artigos 67 e 68 do Código de Defesa do Consumidor, ao tratar da propaganda enganosa identificam com possíveis sujeitos da ação tanto aquele que faz a propaganda (publicitário), como aquele que a veicula.

\subsection{Objeto material e o objeto jurídico do crime.}

O objeto pode ser definido como tudo aquilo contra o que se dirige a conduta criminosa. Nos crimes contra as relações de consumo, podemos identificar tanto um objeto material, quanto um objeto jurídico.

Nas palavras de Victor Eduardo Rios Gonçalves, o objeto material do crime seria resumidamente: "a coisa sobre a qual recai a conduta criminosa". (GONÇALVES, 2011, p.18)

Em se tratando de crime praticado contra as relações de consumo, para Zanellato (1992) o objeto material seria o produto ou o serviço disponibilizado no mercado, conforme definição contida no art. $3^{\circ}, \S \S 1^{\circ}$ e $2^{\circ}$, do CDC:

$\S 1^{\circ}$. Produto é qualquer bem, móvel ou imóvel, material ou imaterial.

$\S 2^{\circ}$. Serviço é qualquer atividade fornecida no mercado de consumo, mediante remuneração, inclusive as de natureza bancária, financeira, de crédito e securitária, salvo as decorrentes das relações de caráter trabalhista. (BRASIL, 1990)

Segundo Filomeno, para efeitos práticos, diz se que, para os fins do Código de Defesa do Consumidor, produto "é qualquer objeto de interesse em dada relação de consumo, e destinado a satisfazer uma necessidade do adquirente, como destinatário final" (FILOMENO, 2001, p. 44).

Já os serviços, segundo Gustavo Pereira Leite Ribeiro, esses podem ser definidos como: "qualquer atividade remunerada, fornecida no mercado de consumo, abrangendo tanto as de natureza pública quanto privada". (RIBEIRO, 2006, p.122). ${ }^{7}$

Quanto ao objeto jurídico do crime esse diz respeito ao bem ou interesse que a lei visa proteger. Fernando Galvão define objeto jurídico como: “o bem jurídico que a norma visa

\footnotetext{
${ }^{7}$ Não obstante a sabia conceituação, adverte o autor que não são todos os serviços públicos que podem ser submetidos ao âmbito de aplicação do Código de Defesa do Consumidor, mas somente os serviços considerados impróprios, quais sejam: “[...] aqueles que são remunerados através de tarifas ou preço público, pois apenas tais atividades podem ser consideradas econômicas, uma vez que não constituem atividade precípua do Estado. Por conseguinte, os serviços propriamente públicos, essenciais para a consecução dos objetivos da sociedade e que não podem ser delegados a terceiros, não se inserem no âmbito de aplicação do Código de Defesa do consumidor. Tais serviços são custeados através de tributos, e a responsabilidade do Estado fulcra-se no art. 37, $\S 6^{\circ}$, da Constituição da República.” (RIBEIRO, 2006, p.122).
} 
proteger", sendo bem jurídico considerado "segundo a consagrada doutrina, qualquer coisa que possa satisfazer uma necessidade humana, e encontra-se tutelado pela norma jurídica.” (GALVÃO, 2007, p. 168).

No caso dos crimes contra as relações de consumo o bem jurídico ou interesse protegido de forma imediata é as relações de consumo, segundo orientações do próprio art. 61, e de forma mediata, a vida, a saúde, a segurança, o patrimônio e a integridade física dos consumidores em geral ${ }^{8}$.

\section{INFRAÇÕES PENAIS EM ESPÉCIE}

Para orientar a atuação e concretizar os objetivos perseguidos pela Política Nacional, o Código de Defesa do Consumidor surgiu no cenário jurídico encravado de princípios próprios. Esses princípios estão espalhados por todos os dispositivos do Código, contudo, consagrados de forma especial, nos artigos $1^{\circ}, 4^{\circ} .6^{\circ}, 7^{\circ}$.

O Código de Defesa do Consumidor ao dispor sobre os princípios a serem atendidos pela Política Nacional das Relações de Consumo listou dentre estes, o principio da transparência e da informação como direitos básicos e impôs ao fornecedor o dever de trazer ao consumidor, com precisão e clareza, todas as informações referentes aos produtos e serviços disponibilizados no mercado de consumo.

Art. $6^{\circ}$ São direitos básicos do consumidor:

III - a informação adequada e clara sobre os diferentes produtos e serviços, com especificação correta de quantidade, características, composição, qualidade e preço, bem como sobre os riscos que apresentem. (BRASIL, 1990).

A imposição legal além de garantir maior segurança busca evitar a incorreta utilização dos produtos e o surgimento de eventuais danos.

Esses esclarecimentos iniciais tornam-se necessário na medida em que muitos dos crimes previstos no CDC, dentre as quais podemos citar os artigos 63, 64, 66, 67, 68 e 69, guardam intima relação com a veiculação de informação e com o dever de informar.

\footnotetext{
${ }^{8}$ Apelação. Crime contra as relações de consumo. Depósito e exposição à venda de mercadorias em condições impróprias. Condenação. Recurso defensivo. Inicial que atende aos requisitos do art. 41 do Código de Processo Penal. Materialidade e autoria fartamente comprovadas. Dolo que se conclui pelas circunstâncias. Desnecessidade de ser provado o perigo concreto das substâncias apreendidas, cuja nocividade a prova colhida apontou ser evidente. Os bens jurídicos tutelados são as "relações de consumo" e a "saúde pública", e só secundariamente os bens jurídicos individuais. Tal técnica de tutela considera ocorrida a lesão com qualquer ataque que rebaixe o nível de segurança do bem secundário. Desprovimento dos recursos. (001959618.2007.8.19.0002 - APELAÇÃO. DES. MARIA HELENA SALCEDO. TJRJ. Julgamento: 03/03/2011 QUINTA CÂMARA CRIMINAL).
} 


\title{
5.1 Omissão de informação sobre a nocividade ou periculosidade de produto
}

Dispõe o art. 63 do Código de Defesa do Consumidor:

Art. 63. Omitir dizeres ou sinais ostensivos sobre a nocividade ou periculosidade de produtos, nas embalagens, nos invólucros, recipientes ou publicidade: Pena Detenção de seis meses a dois anos e multa.

$\S 1^{\circ}$ Incorrerá nas mesmas penas quem deixar de alertar, mediante recomendações escritas ostensivas, sobre a periculosidade do serviço a ser prestado.

$\S 2^{\circ}$ Se o crime é culposo: Pena - Detenção de um a seis meses ou multa. (BRASIL, 1990).

O referido dispositivo encontra-se diretamente relacionado com as normas de proteção prevista no art. $8^{\circ}$ e $9^{\circ}$ do CDC, que assim dispõem:

\begin{abstract}
Art. $8^{\circ}$ Os produtos e serviços colocados no mercado de consumo não acarretarão riscos à saúde ou segurança dos consumidores, exceto os considerados normais e previsíveis em decorrência de sua natureza e fruição, obrigando-se os fornecedores, em qualquer hipótese, a dar as informações necessárias e adequadas a seu respeito. Parágrafo único. Em se tratando de produto industrial, ao fabricante cabe prestar as informações a que se refere este artigo, através de impressos apropriados que devam acompanhar o produto.

Art. $9^{\circ} \mathrm{O}$ fornecedor de produtos e serviços potencialmente nocivos ou perigosos à saúde ou segurança deverá informar, de maneira ostensiva e adequada, a respeito da sua nocividade ou periculosidade, sem prejuízo da adoção de outras medidas cabíveis em cada caso concreto. (BRASIL, 1990).
\end{abstract}

Ante as considerações e conceituações trabalhadas no titulo 3, podemos classificar o crime previsto no art. 63 como um crime omissivo, já que sua consumação se perfaz pela simples abstenção, consubstanciada no núcleo "omitir dizeres" ou "deixar de alertar".

Pune-se a omissão de dizeres ou sinais ostensivos sobre a nocividade ou periculosidade dos produtos nas embalagens, nos recipiente, nos invólucros, na publicidade (SAAD, 1999).

Nas palavras de Dotti "nocividade é a qualidade do que é nocivo, isto é, prejudicial ou danoso; periculosidade é o estado ou situação de perigo a que podem ficar expostas as pessoas ou coisas". (DOTTI, 1992, p. 232).

O sujeito ativo deste delito é a pessoa física que, devendo agir, informando o consumidor por meio de recomendações ostensivas ou publicidade, se omite em apresentá-las. O sujeito passivo é o conjunto de consumidores expostos à prática delituosa.

O crime pode ocorrer modalidade dolosa, conforme previsto no caput e $\S 1^{\circ}$ e na modalidade culposa $\left(\S 2^{\circ}\right)$, caso em que a transgressão ocorre em razão de imprudência, negligência ou imperícia. 
Este crime não admite tentativa, exatamente, porque, inclui-se no rol dos crimes omissivo puros, consumando-se com o simples ato de omitir. (MILHOMENS, 1994).

\subsection{Da omissão quanto aos vícios ou defeitos de produto após sua colocação no mercado.}

$\mathrm{O}$ crime previsto no art. 64 do $\mathrm{CDC}$ tem como objetivo punir o fornecedor que deixa de comunicar à autoridade competente e aos consumidores sobre a existência de vícios e defeitos de produtos após a sua colocação no mercado, e ainda, versa sobre a obrigação do fornecedor ou fabricante de retirá-lo do mercado após a constatação, a saber:

\footnotetext{
Art. 64. Deixar de comunicar à autoridade competente e aos consumidores a nocividade ou periculosidade de produtos cujo conhecimento seja posterior à sua colocação no mercado:

Pena - Detenção de seis meses a dois anos e multa.

Parágrafo único. Incorrerá nas mesmas penas quem deixar de retirar do mercado, imediatamente quando determinado pela autoridade competente, os produtos nocivos ou perigosos, na forma deste artigo. (BRASIL, 1990).
}

Quanto a sua classificação podemos dizer que se trata de crime omissivo puro, já que sua consumação se perfaz por uma simples abstenção.

Verifica-se, contudo, que sua ocorrência pode se dá em duas hipóteses. A primeira quando o fornecedor deixa de comunicar à autoridade competente e aos consumidores a nocividade ou periculosidade dos produtos cujo conhecimento seja posterior à sua colocação no mercado. E a segunda, quando ciente deixa de retirar do mercado os produtos nocivos ou perigosos, após determinação da autoridade competente (LUZ, 1999).

Para Luz (1999) o preceito cominatório contido no art. 64, acaba por dá consequências criminais à norma civil atributiva de direito, prevista no art. 10 do CDC, que veda a introdução no mercado de produtos nocivos ao consumidor, sem as devidas orientações, a saber:

Art. 10. O fornecedor não poderá colocar no mercado de consumo produto ou serviço que sabe ou deveria saber apresentar alto grau de nocividade ou periculosidade à saúde ou segurança.

$\S 1^{\circ} \mathrm{O}$ fornecedor de produtos e serviços que, posteriormente à sua introdução no mercado de consumo, tiver conhecimento da periculosidade que apresentem, deverá comunicar o fato imediatamente às autoridades competentes e aos consumidores, mediante anúncios publicitários.

$\S 2^{\circ}$ Os anúncios publicitários a que se refere o parágrafo anterior serão veiculados na imprensa, rádio e televisão, às expensas do fornecedor do produto ou serviço.

$\S 3^{\circ}$ Sempre que tiverem conhecimento de periculosidade de produtos ou serviços à saúde ou segurança dos consumidores, a União, os Estados, o Distrito Federal e os Municípios deverão informá-los a respeito. (BRASIL, 1990). 
O sujeito ativo do crime é qualquer pessoa física inserta na cadeia de consumo que tenha o dever de comunicar ou recolher no mercado os produtos nocivos ou perigosos. $\mathrm{O}$ sujeito passivo é a coletividade de consumidores.

\subsection{Execução de serviço de alta periculosidade contrariando determinação oficial.}

Prescreve o art. 65 do Código de Defesa do Consumidor:

Art. 65. Executar serviço de alto grau de periculosidade, contrariando determinação de autoridade competente:

Pena - Detenção de seis meses a dois anos e multa.

Parágrafo único. As penas deste artigo são aplicáveis sem prejuízo das correspondentes à lesão corporal e à morte. (BRASIL, 1990).

Verificamos neste artigo a presença de uma norma penal em branco, assim, entendida, como uma norma incompleta em que se exige a complementação por outra norma. Assim, para que o artigo tenha aplicabilidade é necessária a utilização de outra norma que defina de forma clara o que seria considerado "serviço de alta periculosidade".

Trata-se de crime comissivo, praticado mediante uma ação, ou seja, "executar serviço" considerado altamente perigoso.

O sujeito ativo em regra é o prestador de do serviço, mas o tipo poderá atingir também o planejador ou o mandante. (MILHOMENS, 1994).

A execução do serviço caracteriza somente o dolo direto, já a desobediência as determinações da autoridade competente envolve não só o dolo direto, como também, o dolo eventual caracterizado pela assunção do risco. (MILHOMENS, 1994).

Quanto à objetividade jurídica do tipo, Passarelli ensina que:

O fornecedor que deixa de observar a determinação da autoridade competente acerca da execução de um serviço entendendo como de alto grau de periculosidade, e em decorrência vem a matar uma pessoa, atenta contra dois objetos jurídicos diversos (as relações de consumo e a vida humana) devendo ser punido pela violação de ambos. (PASSARELI, 2002, p.68)

Caso haja desdobramento da conduta em lesão corporal ou morte, responde o agente pelo crime previsto no art. 65, sem prejuízo das penas cominadas nos artigos 121 e 129 do Código Penal Brasileiro. 


\title{
5.4 Afirmação falsa ou enganosa sobre produtos ou serviços
}

O dispositivo a seguir tem como objetivo proteger o consumidor contra informação falsa e enganosa. Assim, quando os fornecedores, comerciantes ou publicitários mentem ou omitem ao consumidor sobre as reais características do produto ou serviço que lhe oferece, incorre nas penas do art. 66.

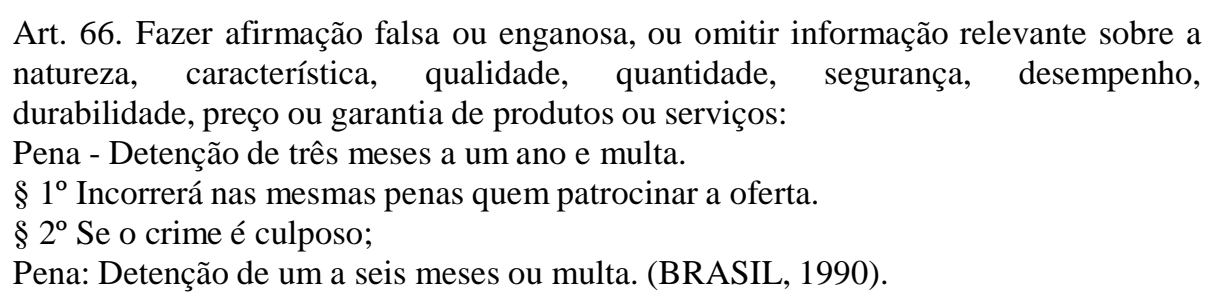

Tanto a afirmação falsa como a enganosa podem levar o consumidor a errar na escolha do produto ou serviço que deseja contratar. Todavia, por se tratar hipóteses diversas torna-se necessário a diferenciação das condutas.

Para Aramy Dornelles da Luz:

\begin{abstract}
A diferença da informação falsa para a enganosa consiste basicamente no emprego ardil, da engenhosidade. È falsa a informação que altera os dados da realidade (mente a respeito da origem da coisa, dos métodos de fabricação, da data da elaboração do produto, etc.), enquanto a enganosa ilude os incautos prometendo um resultado impossível (rejuvenescimento, fim da calvície, emagrecimento, etc.) A omissão se caracteriza pela supressão de elemento informativo relevante. (LUZ, 1999, p.135).
\end{abstract}

O crime prevê condutas distintas, sendo, duas condutas comissivas na modalidade "fazer afirmação falsa" e "fazer afirmação enganosa" e uma conduta omissiva, gerada pela “omissão de informação relevante”. (LUZ, 1999).

Para Milhomens a informação relevante "é aquela estritamente necessária ao conhecimento sobre as características do produto ou serviço. Sua omissão configura a má-fé do fornecedor, sujeitando-o as penas da lei” (MILHOMENS, 1994, p. 150).

A jurisprudência revela ser muito comum a prática deste crime:

APELAÇÃO CRIMINAL - CRIME CONTRA AS RELAÇÕES DE CONSUMO -
INDUZIR O CONSUMIDOR A ERRO POR AFIRMAÇÕES FALSAS EM
ANUNCIO PUBLICITÁRIO - MATERIALIDADE E AUTORIA
COMPROVADAS - CONDENAÇÃO MANTIDA - REDUÇÃO DA
REPRIMENDA - IMPOSSIBILIDADE. 01. Comprovado nos autos que o agente,
mediante anúncio em jornal, induziu o consumidor a erro, fazendo-o acreditar que
estava adquirindo uma motocicleta quando, em verdade, tratava-se de cota de
consórcio, a manutenção de sua condenação é medida que se impõe. 02. Tendo o
sentenciante fundamentado satisfatoriamente a imposição das penas-base acima do


mínimo legal, face à existência de circunstâncias judiciais desfavoráveis ao réu, não há falar-se na alteração do decisum. (Apelação Criminal 1.0024.04.338105-2/001, Rel. Des.(a) Fortuna Grion, $3^{\text {a }}$ CÂMARA CRIMINAL do TJMG, julgamento em 22/03/2011, publicação da súmula em 27/04/2011).

Trata-se de crime que, também, se encontra diretamente relacionado à proteção conferida pelo art. 10 .

\title{
5.5 Publicidade enganosa ou abusiva ${ }^{9}$
}

Preceitua o art. 67 Código de Defesa do Consumidor: "Fazer ou promover publicidade que sabe ou deveria saber ser enganosa ou abusiva: Pena: detenção de três meses a um ano e multa". (BRASIL, 1990).

$\mathrm{O}$ art. $37, \S 1^{\circ}$ do mesmo diploma legal define o que seria a propaganda enganosa $(\S \S$ $1^{\circ}$ e $\left.3^{\circ}\right)$ e a abusiva $\left(\S 2^{\circ}\right)$, a saber:

\begin{abstract}
Art. 37. É proibida toda publicidade enganosa ou abusiva.
$\S 1^{\circ}$ É enganosa qualquer modalidade de informação ou comunicação de caráter publicitário, inteira ou parcialmente falsa, ou, por qualquer outro modo, mesmo por omissão, capaz de induzir em erro o consumidor a respeito da natureza, características, qualidade, quantidade, propriedades, origem, preço e quaisquer outros dados sobre produtos e serviços.

$\S 2^{\circ}$ É abusiva, dentre outras a publicidade discriminatória de qualquer natureza, a que incite à violência, explore o medo ou a superstição, se aproveite da deficiência de julgamento e experiência da criança, desrespeita valores ambientais, ou que seja capaz de induzir o consumidor a se comportar de forma prejudicial ou perigosa à sua saúde ou segurança.

$\S 3^{\circ}$ Para os efeitos deste código, a publicidade é enganosa por omissão quando deixar de informar sobre dado essencial do produto ou serviço. (BRASIL, 1990).
\end{abstract}

Podem ser sujeito ativo do crime: o fornecedor, o publicitário ou o veiculador da informação. A caracterização do crime envolve o dolo direto (o infrator sabia ser enganosa ou abusiva a publicidade) e o dolo eventual, já que o infrator "deveria saber ser a publicidade enganosa ou abusiva”. (SAAD, 1999).

Para Saad a expressão “deveria saber”, utilizada no artigo é totalmente condenável, já que "significa presunção de culpa o que é incompatível com o principio basilar do direito penal hordieno da certeza da culpa do delinquente”. (SAAD, 1999, p. 546).

Segundo Milhomens esta tipificação na forma como é colocada acaba por equiparar a conduta dolosa à culposa, todavia, essa constatação é equivocada, já que "não há dolo do agente quando este toma conhecimento do caráter enganoso ou abusivo da publicidade após

\footnotetext{
${ }^{9}$ Ver art. $6^{\circ}$, IV do CDC; Art. 17 da Lei 4.680/65; Decreto nº $.57 .690 / 66$ e art. $7^{\circ}$, VII, da Lei 8.137/90.
} 
veicula-la, por inexistência, de acordo com a melhor doutrina, do dolo subsequente". (MILHOMENS, 1994, p.152).

No que diz respeito a objetividade jurídica a norma é projetada de duas formas, já que busca conferir proteção as relações de consumo, e também, a saúde e a segurança dos consumidores.

\subsection{Induzimento do consumidor à comportamento prejudicial ou perigoso}

A infração capitulada no art. 68 visa penalizar aquele que faz ou promove publicidade, sabendo ou devendo saber de sua potencialidade em induzir o consumidor à prática de conduta lesiva à sua própria saúde ou segurança.

Art. 68. Fazer ou promover publicidade que sabe ou deveria saber ser capaz de induzir o consumidor a se comportar de forma prejudicial ou perigosa a sua saúde ou segurança: Pena: detenção de seis meses a dois anos e multa. (BRASIL, 1990).

Trata-se de crime de perigo concreto, em que se exige a demonstração da probabilidade de dano à saúde ou segurança do consumidor. Em razão disso, concorrem com esta infração os crimes “contra a saúde pública” previstos nos arts. 272, 273, 275 e 277 do Código Penal Brasileiro $^{10}$.

É admissível na modalidade dolosa, e assim, como o tipo previsto no artigo anterior, envolve presunção de culpa.

\footnotetext{
${ }^{10}$ Art. 272 - Corromper, adulterar, falsificar ou alterar substância ou produto alimentício destinado a consumo, tornando-o nociva à saúde ou reduzindo-lhe o valor nutritivo: Pena - reclusão, de 4 (quatro) a 8 (oito) anos, e multa. $\S 1^{\circ}$-A - Incorre nas penas deste artigo quem fabrica, vende, expõe à venda, importa, tem em depósito para vender ou, de qualquer forma, distribui ou entrega a consumo a substância alimentícia ou o produto falsificado, corrompido ou adulterado. $\S 1^{\circ}$ - Está sujeito às mesmas penas quem pratica as ações previstas neste artigo em relação a bebidas, com ou sem teor alcoólico. $\S 2^{\circ}$ - Se o crime é culposo: Pena - detenção, de 1 (um) a 2 (dois) anos, e multa. Art. 273 - Falsificar, corromper, adulterar ou alterar produto destinado a fins terapêuticos ou medicinais: Pena - reclusão, de 10 (dez) a 15 (quinze) anos, e multa. $§ 1^{\circ}$ - Nas mesmas penas incorre quem importa, vende, expõe à venda, tem em depósito para vender ou, de qualquer forma, distribui ou entrega a consumo o produto falsificado, corrompido, adulterado ou alterado. $\S 1^{\circ}$-A - Incluem-se entre os produtos a que se refere este artigo os medicamentos, as matérias-primas, os insumos farmacêuticos, os cosméticos, os saneantes e os de uso em diagnóstico. $\S 1^{\circ}$-B - Está sujeito às penas deste artigo quem pratica as ações previstas no $\S 1^{\circ}$ em relação a produtos em qualquer das seguintes condições: I - sem registro, quando exigível, no órgão de vigilância sanitária competente; II - em desacordo com a fórmula constante do registro previsto no inciso anterior; III - sem as características de identidade e qualidade admitidas para a sua comercialização; IV - com redução de seu valor terapêutico ou de sua atividade; V - de procedência ignorada; VI

- adquiridos de estabelecimento sem licença da autoridade sanitária competente. $\S 2^{\circ}$ - Se o crime é culposo: Pena - detenção, de 1 (um) a 3 (três) anos, e multa. Art. 275 - Inculcar, em invólucro ou recipiente de produtos alimentícios, terapêuticos ou medicinais, a existência de substância que não se encontra em seu conteúdo ou que nele existe em quantidade menor que a mencionada: Pena - reclusão, de 1 (um) a 5 (cinco) anos, e multa. Art. 277 - Vender, expor à venda, ter em depósito ou ceder substância destinada à falsificação de produtos alimentícios, terapêuticos ou medicinais: Pena - reclusão, de 1 (um) a 5 (cinco) anos, e multa.
} 


\subsection{Publicidade sem apoio técnico ou cientifico}

Assim dispõe o art. 36 do CDC:

Art. 36. A publicidade deve ser veiculada de tal forma que o consumidor, fácil e imediatamente, a identifique como tal.

Parágrafo único. O fornecedor, na publicidade de seus produtos ou serviços, manterá, em seu poder, para informação dos legítimos interessados, os dados fáticos, técnicos e científicos que dão sustentação à mensagem. (BRASIL, 1990).

Do artigo citado depreende-se a obrigação do fornecedor de manter dados fáticos, técnicos e científicos que sustentam a mensagem para informação dos consumidores.

Os dados necessários à informação devem ser organizados e arquivados pelo fornecedor, garantindo-se o livre acesso dos legítimos interessados.

A informação deve ser ainda adequada e clara, sendo vedada a publicidade enganosa ou abusiva, que cause danos ao consumidor ou exponha a risco a sua vida, saúde ou segurança. (MILHOMENS, 1994).

Caso o fornecedor se omite e deixa de organizar essas informações incorre nas penas do art. 69 do $\mathrm{CDC}$, que assim dispõe: "Deixar de organizar dados fáticos, técnicos e científicos que dão base à publicidade: Pena: Detenção de um a seis meses ou multa". (BRASIL, 1990).

Para Filomeno a proteção conferida pelo art. 69 é indispensável na medida em que:

Se necessário o ajuizamento de qualquer ação, que no âmbito individual, quer no âmbito coletivo, em se tratando de publicidade enganosa ou abusiva (vide art.37 e seus parágrafos já mencionados passo atrás) o judiciário terá melhores condições de aquilatar sobre a tendenciosidade ou não de determinada publicidade ou então os órgãos administrativos incumbidos de seu controle, sobretudo, na área da saúde. (FILOMENO, 2001, p. 658).

Trata o tipo de crime instantâneo que consuma no momento em que se faz a publicidade, sem a prévia coleta de dados fáticos, técnicos ou científicos que comprovem a veracidade do que se comunica ao mercado de consumo (SAAD, 1999).

\subsection{Reposição de peça usada}

Estabelece o art. 21 do Código de Defesa do Consumidor:

Art. 21. No fornecimento de serviços que tenham por objetivo a reparação de qualquer produto considerar-se-á implícita a obrigação do fornecedor de empregar 
componentes de reposição originais adequados e novos, ou que mantenham as especificações técnicas do fabricante, salvo, quanto a estes últimos, autorização em contrário do consumidor. (BRASIL, 1990).

A desobediência dos preceitos estabelecidos no artigo citado configura delito tipificado no art.70 do CDC, a saber: "Empregar na reparação de produtos, peça ou componentes de reposição usados, sem autorização do consumidor. Pena Detenção de três meses a um ano e multa”. (BRASIL, 1990).

Busca-se com esse crime proteger o consumidor contra atitude arbitraria do prestador que, não obstante exija do consumidor pagamento por peças novas, acabar por utilizar na reparação peças velhas ou recondicionadas.

O sujeito passivo neste caso pode ser a pessoa física que fornece ou prestar o serviço, ou ainda, o empregado que o executa o serviço de reparação. Já o sujeito passivo pode ser qualquer consumidor.

Esse crime tem como objeto jurídico a proteção às relações de consumo, e ainda, o patrimônio do consumidor vítima do delito.

\subsection{Do procedimento irregular de cobrança}

Prescreve o art. 42 do Código de Defesa do Consumidor:

Art. 42. Na cobrança de débitos, o consumidor inadimplente não será exposto a ridículo, nem será submetido a qualquer tipo de constrangimento ou ameaça.

Parágrafo único. $\mathrm{O}$ consumidor cobrado em quantia indevida tem direito à repetição do indébito, por valor igual ao dobro do que pagou em excesso, acrescido de correção monetária e juros legais, salvo hipótese de engano justificável. (BRASIL, 1990).

A cobrança abusiva de divida que se refere o art. 42 é também um delito tipificado no art.71 do Código de Defesa do Consumidor.

Art. 71. Utilizar, na cobrança de dívidas, de ameaça, coação, constrangimento físico ou moral, afirmações falsas incorretas ou enganosas ou de qualquer outro procedimento que exponha o consumidor, injustificadamente, a ridículo ou interfira com seu trabalho, descanso ou lazer: Pena: Detenção de três meses a um ano e multa. (BRASIL, 1990).

O crime se consuma com a verificação de quaisquer das modalidades de cobrança arbitraria que interfira na vida privada do consumidor. 
Infringe também a norma aquele que faz afirmações falsas, incorretas ou enganosas ou de qualquer outra forma exponha o consumidor, injustificadamente, ao ridículo ou interfira no seu trabalho, descanso ou lazer. Para Passarelli:

\begin{abstract}
O consumidor não pode ser constrangido, indevidamente, ao pagamento de suas dividas. Por essa razão é valido o emprego do advérbio "injustificadamente" na letra da lei. Por ilustração, o constrangimento moral justificado em lei não é criminoso. Assim sendo, o fornecedor pode encaminhar o nome do consumidor inadimplente ao cartório de protesto ou ao serviço de proteção ao crédito (SPC). Nessas hipóteses obviamente, não incorrerá em crime. Pune-se na realidade, a natureza abusiva do procedimento empregado na cobrança da dívida. (PASSARELLI, 2002, p. 86)
\end{abstract}

São variadas as formas de se praticar o crime, já que este enuncia modalidades diferentes, ainda que com o mesmo objetivo, qual seja constranger o consumidor a pagar uma dívida. (SAAD, 1999).

\title{
5.10 Acesso aos bancos de dados
}

O direito do consumidor ao acesso as informações encontra-se assegurado no art. 43, $\S \S 1^{\circ}$ e $2^{\circ}$ do Código de Defesa do Consumidor:

\footnotetext{
Art. 43. O consumidor, sem prejuízo do disposto no art. 86, terá acesso às informações existentes em cadastros, fichas, registros e dados pessoais e de consumo arquivados sobre ele, bem como sobre as suas respectivas fontes.

$\S 1^{\circ}$ Os cadastros e dados de consumidores devem ser objetivos, claros, verdadeiros e em linguagem de fácil compreensão, não podendo conter informações negativas referentes a período superior a cinco anos.

$\S 2^{\circ}$ A abertura de cadastro, ficha, registro e dados pessoais e de consumo deverá ser comunicada por escrito ao consumidor, quando não solicitada por ele. (BRASIL, 1990)
}

O fornecedor de produtos e serviços que restringe o acesso do consumidor as informações garantidas pelo art. 43 e parágrafos está sujeito a pena de detenção de 6 (seis) meses a 1 (um) ano e multa, conforme preceitua o art. 72 do CDC, a saber: "Impedir ou dificultar o acesso do consumidor às informações que sobre ele constem em cadastros, banco de dados, fichas e registros: Pena: detenção de seis meses a um ano ou multa.” (BRASIL, 1990).

Trata-se de crime doloso e que não admite tentativa, isso porque a simples tentativa, qual seja, dificultar o acesso já configura crime. Desta forma, o crime se consuma em si mesmo e não há possibilidade de impedir a sua ocorrência por interposta pessoa ou por circunstâncias alheias a vontade do agente. 


\subsection{Correção de informação inexatas}

O art. 73 é uma extensão do art. 72, que também, impõe punição de detenção de um a seis meses ou multa ao fornecedor que deixa de corrigir informações inexatas sobre o consumidor constante em banco de dados.

Art. 73. Deixar de corrigir imediatamente informação sobre consumidor constante de cadastro, banco de dados, fichas ou registros que sabe ou deveria saber ser inexata: Pena: Detenção de um a seis meses ou multa. (BRASIL, 1990)

Essa proteção é garantida, também, pelo art. $43, \S \S 3^{\circ}, 4^{\circ}$ e $5^{\circ}$ do Código de Defesa do Consumidor, que assim dispõe:

Art. $43[\ldots] \S 3^{\circ} \mathrm{O}$ consumidor, sempre que encontrar inexatidão nos seus dados e cadastros, poderá exigir sua imediata correção, devendo o arquivista, no prazo de cinco dias úteis, comunicar a alteração aos eventuais destinatários das informações incorretas. $\S 4^{\circ}$ Os bancos de dados e cadastros relativos a consumidores, os serviços de proteção ao crédito e congêneres são considerados entidades de caráter público. $\S 5^{\circ}$ Consumada a prescrição relativa à cobrança de débitos do consumidor, não serão fornecidas, pelos respectivos Sistemas de Proteção ao Crédito, quaisquer informações que possam impedir ou dificultar novo acesso ao crédito junto aos fornecedores. (BRASIL, 1990).

Trata-se de crime de perigo concreto, dependendo a sua configuração da demonstração de perigo.

\subsection{Da entrega do termo de garantia.}

O art. 50 do Código de Defesa do Consumidor ao dispor sobre a garantia contratual impôs ao fornecedor, quando da comercialização de produtos e serviços, a obrigação de fornecer ao consumidor termo de garantia devidamente escrito, com informações claras e adequadas a respeito das garantias dos produtos ou serviços, tais como, prazos, lugares de exercício e os ônus a cargo do consumidor.

Art. 50. A garantia contratual é complementar à legal e será conferida mediante termo escrito.

Parágrafo único. O termo de garantia ou equivalente deve ser padronizado e esclarecer, de maneira adequada em que consiste a mesma garantia, bem como a forma, o prazo e o lugar em que pode ser exercitada e os ônus a cargo do consumidor, devendo ser-lhe entregue, devidamente preenchido pelo fornecedor, no ato do fornecimento, acompanhado de manual de instrução, de instalação e uso do produto em linguagem didática, com ilustrações. (BRASIL, 1990). 
O descumprimento dessa obrigação pelo fornecedor tipifica a figura delituosa de que trata o art. 74 do Código de Defesa do Consumidor, que assim dispõe: "Deixar de entregar ao consumidor o termo de garantia adequadamente preenchido e com especificação clara de seu conteúdo. Pena Detenção de um a seis meses ou multa.” (BRASIL, 1990).

Para Luz o descumprimento da determinação legal prevista no artigo supramencionado pode ser tipificado como crime de desobediência, que conhece dois desdobramentos. O primeiro se daria em razão da não há entrega do termo de garantia, já o segundo quando há entrega, contudo, o termo não se encontra preenchido adequadamente. (LUZ, 1999). Trata-se de crime omissivo que só conhece a modalidade dolosa.

\section{CONSIDERAÇÕES FINAIS}

Conforme analisado, até bem pouco tempo atrás os consumidores e fornecedores tinham plena liberdade de pactuar as regras relativas a aquisição e fornecimento de produtos e serviços. Todavia, em razão da propagação do crédito e do consumo desenfreado identificouse a presença de um "vulnerável” nesta relação.

$\mathrm{Na}$ relação de consumo não dispondo o consumidor do controle sobre a produção e venda dos objetos ou serviços que lhes são destinados, acaba-se submetendo as condições e exigências impostas pelo economicamente mais forte.

Ante o evidente desequilíbrio tornou-se necessário a criação de instrumentos jurídicos destinados a estabelecer o equilíbrio nesta relação.

Não obstante, a existência prévia de outras legislações extravagantes destinadas a conferir proteção às relações de consumo e consumidores, o surgimento do Código de Defesa do Consumidor foi sem dúvida uma acontecimento muito importante. Isso porque o Código além de trazer normas de direito privado, também, armou o consumidor com instrumentos sancionatórios de caráter penal.

É evidente que a instituição dos crimes de consumo seja pelo do Código de Defesa do Consumidor, seja pela Lei $\mathrm{n}^{\circ}$. 8.137/90 assumem papel muito importante na defesa dos direitos dos consumidores. Todavia, verifica-se que não obstante a existência e relevância dessas normas de proteção, a de se reconhecer que os consumidores nem sempre são estimulados a denunciar as infrações contra eles cometidas, seja, em razão de comodidade, ausência de credibilidade na justiça ou mesmo falta de informações acerca desses tipos penais. 
Tendo em vista questão levantada, espera-se que o resultado alcançado possa fornecer aos consumidores informações capazes de auxilia-los na defesa de seus direitos e também, na busca de maior efetividade dos tipos penais analisados.

\section{REFERENCIAS}

ALVIM, Arruda, et al. Código do Consumidor Comentado. 2. ed. rev. e ampl. São Paulo: Revista dos Tribunais; 1995.

BITENCOURT. Cezar Roberto. Tratado de Direito Penal. Parte Geral. v. I. $3^{\text {a }}$ ed. São Paulo: Saraiva, 2003.

BRASIL. Constituição (1988) Constituição da República Federativa do Brasil. Brasília: Senado: 1988. Disponível em: http://www.planalto.gov.br/ccivil_ 03/constituicao/constituicaocompilado.htm Acesso em: 03 de março de 2015.

BRASIL. Constituição Federal. Código Civil. Código de Processo Civil. Organizador Yussef Said Cahali. São Paulo: Editora Revista dos Tribunais, 2014.

BRASIL. Decreto-Lei no 2.848, de 7 de dezembro de 1940. Código Penal. Diário Oficial da União. Rio de Janeiro, 31 de dez. de 1940. Disponível em: http://www.planalto.gov.br/ccivil_03/decreto-lei/del2848.htm Acesso em: 03 de março de 2015.

BRASIL. Lei $\mathbf{n}^{\circ}$. 8.078, de 11 de setembro de 1990. Dispõe sobre a proteção do consumidor e dá outras providências. Diário Oficial da União. Brasília, 12 de set. 1990.

DOTTI, René Ariel. Comentários ao Código do Consumidor. São Paulo: Forense, 1992.

FARIAS, Cristiano Chaves de. A proteção do consumidor na era da globalização. Revista de Direito do Consumidor. São Paulo: Revista dos Tribunais. n. 41, p. 81-95, jan-mar. 2002.

FILOMENO, José Geraldo Brito. Manual de Direito do Consumidor. 6ed. São Paulo: Atlas, 2000.

ROCHA, Fernando A. N. Galvão da. Direito Penal. Parte Geral. Curso Completo. 2a ed. rev., atual. e ampl. Belo Horizonte: Del Rey, 2007.

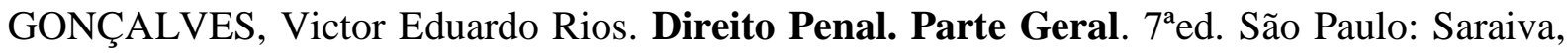
2011.

GRINOVER, Ada Pellegrini, et al. Código Brasileiro de Defesa do Consumidor: comentado pelos autores do anteprojeto. $6^{\mathrm{a}}$ ed., Rio de Janeiro: Forense Universitária, 2000 .

LUZ, Aramy Dornelles da. Código do Consumidor Anotado. $1^{\mathrm{a}}$ ed. São Paulo: Juarez Oliveira, 1999. 
MARINS, James. Responsabilidade da empresa pelo fato do produto. São Paulo: Revista dos Tribunais, 1993.

MARQUES, Claudia Lima, et al. Comentários ao Código de Defesa do Consumidor. $2^{\mathrm{a}}$ ed. rev., atual. e ampl. São Paulo: Revista dos Tribunais, 2006.

MILHOMENS, Jonatas, et al. Manual do Direito do Consumidor. Rio de Janeiro: Forense, 1994.

NASCIMENTO, Tupinambá Miguel Castro do. Comentários ao Código do Consumidor. Rio de Janeiro: Aide, 1991.

NERY JÚNIOR, Nelson. Os princípios gerais do Código Brasileiro de Defesa do Consumidor. Revista de Direito do Consumidor $n^{\circ}$ 03. São Paulo: Ed. Revista dos Tribunais, 1992.

NERY JÚNIOR, Nelson. Crimes contra as relações de consumo. Justitia. São Paulo, nº. 59, p. 14-23, jan/dez, 1998.

NUNES, Luiz Antonio Rizzatto. Comentários ao Código de Defesa do Consumidor: direito material (arts. $1^{\circ}$ a 54). São Paulo: Saraiva, 2000.

OLIVEIRA, José Carlos de. Código de Proteção e Defesa do Consumidor. $2^{\mathrm{a}}$ ed. São Paulo: LED, 1999.

PASSARELLI, Eliana. Dos crimes contra as relações de consumo: Lei Federal $\mathbf{n}^{\mathbf{0} 8.078 / 90 .}$ São Paulo: Saraiva, 2002.

RIBEIRO, Gustavo Pereira Leite. A arbitragem nas relações de consumo. Curitiba: Juruá, 2006.

SAAD, Eduardo Gabriel. Comentários ao Código de Defesa do Consumidor. $4^{a}$ ed. São Paulo: Revista dos Tribunais, 1999.

ZANELLATO, Marco Antônio. O direito penal econômico e o direito penal de defesa do consumidor como instrumento de resguardo da ordem pública econômica. Justitia. São Paulo, no. 54, p. 84-101, out/dez, 1992. 